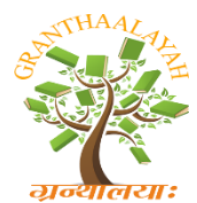

\author{
INTERNATIONAL JOURNAL OF R
GRANTHAALAYAH \\ A knowledge Repository
}

Science

\title{
USE OF INSECTICIDES AMONG COWPEA FARMERS IN FUFORE LOCAL GOVERNMENT AREA OF ADAMAWA STATE, NIGERIA
}

\author{
A.S. Haddabi *1 \\ ${ }^{* 1}$ Department of Agricultural Economics and Extension, Faculty of Agriculture \\ Adamawa State University, Mubi, Nigeria
}

\begin{abstract}
Cowpea is a good and cheapest source of protein to human beings and feeds to livestock. Production of the crop is accompanied with insect pests problems which makes the use of insecticides imperative. The broad objective was to analyze the use of insecticides among cowpea farmers in Fufore Local Government Area, Adamawa State, Nigeria, and the specific objectives were to describe the socio-economic characteristics of the respondents, identify the common insecticides used by the respondents, determine the costs of insecticides incurred per unit area to control cowpea pests by the respondents, determine the socio-economic factors influencing the use of insecticides for control of cowpea pests by the respondents, and identify the major constraints encountered by the respondents in cowpea production in the study area. Data for this research were obtained from primary source with the aid of questionnaires. Data collected were analyzed using descriptive statistics and linear regression. The linear regression results shows that the use of insecticides by the respondents is influenced directly by their educational level (0.014115), Household size (0.004386), Farming experience (0.008612) and Farm size (0.036816). Similarly, age of the respondents inversely affect their decision to use insecticides (-0.003066). An average of N3,737.17 was incurred in procuring insecticides to control cowpea pests per hectare. The entire respondents used modern insecticides. The common insecticides used were Cypermethrim 10EC or $10 \% \mathrm{EC}$ and Lambda-cyhalothrim, were mostly used. Majority of the respondents $(29.05 \%)$ were at their active age of 40-49 years, most of them (84.76\%) were male, $90.48 \%$ were married, $32.86 \%$ (majority) had family size $6-10$, and $56.67 \%$ had one form of formal education of another, while $73.81 \%$ were engaged in farming. It could be concluded that, the use of insecticides for control of pests in cowpea production will not only lead to food security among farmers in the production area, but will help in general food security all over the country since cowpea is an important protein food consumed far beyond the immediate production area. Based on the above, I recommend that: effective insecticides should be made available to farmers when required, youths should be encouraged to embark on cowpea production, government should have a political will towards agriculture so as to improve extension services, and cowpea farmers should adopt integrated pest management (IPM) as a remedy to pest problems in cowpea production.
\end{abstract}

Keywords: Cowpea; Insecticides; Farmers; Fufore; Adamawa. 
Cite This Article: A.S. Haddabi. (2019). "USE OF INSECTICIDES AMONG COWPEA FARMERS IN FUFORE LOCAL GOVERNMENT AREA OF ADAMAWA STATE, NIGERIA." International Journal of Research - Granthaalayah, 7(12), 150-176. https://doi.org/10.29121/granthaalayah.v7.i12.2019.309.

\section{Introduction}

\subsection{Background of The Study}

Cowpea (Vigna unguiculata $\{\mathrm{L}\}$ Walp) is a tropical, annual herbaceous legume which belongs to the family Papilionaceae (Fabaceae), order leguminosae and genus Vigna (Oyewale et al., 2014). The name "Cowpea" derives from when it was an important livestock feed for cows in the United States (International Institute for Tropical Agriculture, 2014). It originated and was domesticated in Southern Africa and was later moved to East and West Africa and Asia (IITA, 2014). Cowpea is a major staple food crop in sub-Saharan Africa, especially in the dry savanna region of West Africa (Dugje et al., 2009). The nutrient content of cowpea seed is protein (24.8\%), Fat (1.9\%), fibre $(6.3 \%)$, carbohydrate $(63.6 \%)$ Thiamine $(0.00074 \%)$, Riboflavin $(0.00042 \%)$ and Niacin $(0.00281 \%)$ (Davis et al., 1991). More than 11 million hectares of Cowpea are harvested worldwide, $97 \%$ of which is in Africa. Nigeria harvest 4.5 Million hectares annually (IITA, 2014) being the leading producer. According to CGIAR, 2014, Niger is the second largest producer followed by Burkina Faso, Myanmar, Cameroun, and Mali \{Consultative Group for International Agricultural Research, -(CGIAR,) 2014\}. The average yield worldwide is estimated at 450kg/ha, while 38 million households (194 million people) grow cowpea in sub-Saharan Africa (CGIAR, 2014). However, the domestic production of cowpea is in the hands of small scale farmers who obtain yield of 200-250 kg/ha due to lack of improved technologies (Musa et al., 2010). Insect pests are major constraints to cowpea production in West Africa. The crop is severely attacked at every stage of its growth by a myriad of insects that make the use of tolerant varieties and insecticide sprays imperative. Damage by insect pests on cowpea can be as high as $80 \%-100 \%$ if not effectively controlled (Dugje et al., 2009). The major insect pests which severely damage cowpea during all growth stages are the cowpea aphid (Aphis Craccivora Koch), foliage beetles (Ootheca sp., medythia spp.), the flower bud thrips (Mega- lurothrips sjostedti trybon,) the legume pod borer (Maruca vitrata fabricius) and the sucking bugs complex of which Clavigralla Spp., Nezara viridula Fab and Aspavia armigera L and storage pest (Bruchid) are most important and are prevalent, without their control, reasonable grain yield cannot be obtained (Gumel, 2008; Egho, 2011).

Several control measures are available but chemicals are most effective, giving several fold increase in grain yield (Egho, 2011). Pesticides may be available in different spray formulations, such as emulsions or wettable powders (Van Emden, 1989). The history of insecticide use dates back many centuries, certainly to before 1000 B.C., when it is mentioned by Homer, but the real landmark in terms of modern Agriculture is the spread of Colorado beetle (Leptinotarsa decemlineata) across the United States in the second half of the nineteenth century (Van Emden, 1989). Insecticides were mainly of three kinds (contact insecticides, Fumigant insecticides and stomach poisons). The insecticides work in a variety of ways, poisoning either the nervous system or respiratory system (Van Emden, 1989). Chemical pest control in cowpea production is influenced by farmers' age, marital status, educational qualification, the desires of farmers for 
higher yields and the contact with extension activities (Omolehin et al., 2007). Insecticides were mainly of three kinds (contact insecticides, Fumigant insecticides and stomach poisons).

Fufore Local Government Area is one of the largest cowpea growing regions in Adamawa State (Fufore LGA at a Glance, 2013). The crop serves as a staple food to the people and the major cash crop and fodder among the rural farmers, but a wide spectrum of pests attack on the crop is a major impediment to its production thereby low grain yields are recorded.

\subsection{Statement of the Problem}

Cowpea suffers a set back as it is attacked by many insect pests throughout it geographical ranged. Damage by insect pests on cowpea can be as high as $80 \%$ - 100\% if not effectively controlled (Dugje et al., 2009).

The product of Cowpea, being one of the most important crops produced in the study area as food and cheapest source of protein, good source of fodder for livestock and as cash crop to rural farmers, has been undermined by the prevalence of wide spectrum of pests which hinders its optimum yield despite large hectarages under cultivation. With long history in cultivating the crop, yet no successful remedy to pests problems so far attained in the study area. Various research on aspects of Cowpea production was conducted within Adamawa State, example effect of sowing date on yield components of cowpea (Vigna unguiculata L.Walp) in Mubi-North Local Government Area, Adamawa State, Nigeria (Futuless et al., 2010), profitability of sole Cowpea production in Gombi Zone of Adamawa State Agricultural Development Programme, Nigeria (Isah et al., 2013), investigation on production constraints and adoption of inorganic insecticides and spraying regime in management of Cowpea (Vigna unguiculata L.Walp) insects in Mubi Zone, Nigeria (Elizabeth et al., 2014 ), evaluation of yield and yield attributes of some cowpea (Vigna unguiculata L.Walp) varieties in Northern Guinea Savanna (Futuless and Bake, 2010), determinant of cost efficiency in Cowpea production: A case study of Adamawa State, Nigeria (Zalkuwi et al., 2014), Effect of Karate 2.5EC, Neem seed aqueous extract and cigarette filter extract on the yield of Ife-Brown in Mubi, Adamawa State, Nigeria (Shinggu and Daniel, 2010) and promotion of integrated pest management in Cowpea production in Fufore Local Government Area, Adamawa State, Nigeria (Haddabi, 2009) among others were relevant, but does not address the socioeconomic factors influencing application of insecticides for control of Cowpea pests among rural farmers in the study area, which prompted this research work. However, in recent decades, some efforts through extension services were rendered in advising farmers on the use of recommended insecticides as a solution to pests problems; assorted insecticides were developed and available in markets to enable harvest of surplus grain yield and increase in income on a sustainable basis in a consistent manner. Against this background the research has attempted to provide answers to the following research questions:

1) what are the socio-economic characteristics of cowpea farmers in the study area?

2) what are the common insecticides used in the study area?

3) what is the cost of insecticides incurred per unit area to control cowpea pests in the study area?

4) what are the socio-economic factors influencing application of insecticides for control of cowpea pests in the study area? 
5) what are the major constraints encountered by farmers in cowpea production in the study area?

\subsection{Objectives of the Study}

The broad objective of the study was to analyse the use of insecticides for control of cowpea pests by cowpea farmers of Fufore Local Government Area, Adamawa State, Nigeria.

The specific objectives were to:

1) describe the socio-economic characteristics of the respondents

2) identify the common insecticides used by the respondents

3) determine the costs of insecticides incurred per unit area to control cowpea pests by the respondents

4) determine the socio-economic factors influencing the use of insecticides for control of cowpea pests by the respondents

5) identify the major constraints encountered by respondents in cowpea production in the study area

\subsection{Justification of the Study}

Cowpea is one of the main crops grown in the study area and provides the cheapest and affordable source of protein to the people compared to meat, fish, eggs and milk. It serves as the best source of fodder in livestock fattening in the study area of which many families were engaged. However, the menace of cowpea pests renders the crop vulnerable throughout its growth stages which prompts the use of insecticides to control cowpea pests. Chemical pest control in cowpea production is influenced by farmers' age, marital status, educational qualification, the desire of farmers for higher yields and the contact with extension activities (Omolehin et al., 2007).

Also, chemical pest control could help the farmers in making sure that higher yields are obtained from cowpea production thus helping the rural farmers to become food secured since cowpea are very good protein rich food. Moreover, farmers that apply insecticides obtain higher yields, and realize marketable surplus that will lead to higher income generation thereby reducing poverty among the rural farmers (Omolehin et al., 2007).

Cowpea production and processing is propelling a silent revolution in Nigeria, as incomes from the crop improve rural livelihoods. Cowpea farmers using improved cowpea varieties and management practices have seen their incomes increased by an average of 55\% (CGIAR, 2014). The result of this research will be useful to farmers, policy makers and extension workers. It will also serve as a reference material for academic pursuit.

\subsection{Scope of the Study}

The research is narrowed to Fufore Local Government Area of Adamawa State, Nigeria. The study covers aspects of cowpea production such as socio-economic factors influencing the use of insecticides for control of cowpea pests, as well as production statistics, economic significance 
and origin of the crop, together with socio-economic variables of cowpea growers in the study area.

\section{Literature Review}

\subsection{Historical Background of Insecticides and Their Use for Control of Cowpea Pests}

Chemicals that are used for pest control are known as pesticides (Omolehin et al., 2007). Pesticides are chemicals designed to destroy, prevent, repel, or mitigate any form of life declared to be a pest (Acquaah, 2005). The term "insecticide" in a broad sense, includes substances used for the destruction of insects and related pests (Kochhar, 1986). For centuries, various kinds of plant materials have been used to combat insects, rats and other pests in different parts of the world e.g Pyrethrum, nicotine, derris and cube before development of DDT (Dichlorodiphenyltrichloroethane), aldrin, malathion, benzene hexachlorides, etc (Kochhar, 1986). By December 1969, there were more than 900 different active pesticides available in more than 60,000 preparations. The number has perhaps increased substantially since then (Kochhar, 1986).

Insecticides may be available in different spray formulations, such as emulsions or wettable powders. Trying different formulations may reveal differences in selectivity between them, which again may be due to the behaviour of insects in relation to the type of deposit left on the plants, the persistence of different formulations and the contribution of the different additives in the formulation to the toxicity of the deposit (van Emden, 1989).

Chemical pest control could help the farmers in making sure that higher yields are obtained from cowpea production thus helping the rural farmers to become food secured since cowpea are very good protein rich food. Moreover, farmers that apply pesticides to control cowpea pests obtain higher yields, this helps them realize marketable surplus that will lead to higher income generation thereby reducing poverty among the rural farmers (Omolehin et al., 2007).

Certainly, insecticides formulation and the method of application can have almost great influence on the efficiency and selectivity of kill than the choice of active ingredient (van Emden, 1989). Most single alternative methods have problems which prevent those becoming general alternatives to pesticides, particularly in relation to the several pests that often attack one crop (van Emden, 1989). Chemical pesticides are and will continue to be of considerable importance in food production (Baur, 1984). Pesticides can contribute to increased agricultural productivity if their use is limited and targeted. When using chemicals, positive impacts should clearly outweigh the negative ones (Fleischer, 2006).

Insecticide use on cowpea has a long history. It is the most widely known form of pest control on this crop. Traditional cowpea growers in Africa do not habitually use insecticides as reflected in poor yields they obtain. In many countries in Asia, pest control is mainly insecticide based, and for many commercial growers it is the only way. However, insecticides are the fire-fighting analog in cowpea pest control, a function for which they remain unrivaled (Jackai and Adalla, 1997). Several control measures are available but chemicals are most effective, giving several fold increase in grain yield (Egho, 2011). 


\subsection{Origin, Distribution and Statistics on Cowpea Production}

Cowpea (Vigna unguiculata [L] Walp) is a Tropical, annual, herbaceous legume, which belongs to the family papilionaceae (Fabaceae), order leguminoseae and genus Vigna (Oyewale et al., 2014), and originated and domesticated in Southern Africa and later spread to East and West Africa and Asia (CGIAR, 2014). Based on the presence of wild progenitors of cowpea in west and Central Africa, the region was the center of domestication of cowpea. Cowpea is extensively cultivated in Africa, Asia, Australia, Brazil, the carribean's, India and the United States of America (Oyewale et al., 2014). The major areas of production in central and West Africa, which account for about $89 \%$ of the total area of world production, are Nigeria, Niger, Mali, BurkinaFaso, Senegal, Cameroon and Democratic Republic of Congo (Oyewale et al., 2014). Modest amounts also emanate from Mozambique, Tanzania, Uganda, Sudan, Kenya and Somalia. Other producers are Myanmar, Haiti, Serberia, Sri Lanka and Egypt (Oyewale et al., 2014).

An estimated 14.5 million ha of land is planted to cowpea each year world wide (CGIAR, 2014), 97\% of which is in Africa (IITA, 2014). Global production of dried peas in 2010 was 5.5 million metric tonnes; Africa was responsible for $94 \%$ of this (CGIAR, 2014). More than 4 million tonnes of peas of all sorts are consumed worldwide (IITA, 2014). The main producing areas in Nigeria are within the Guinea and Sudan Savannas (Oyewale et al., 2014). However, some appreciable quantities are grown in the South -West, which has two growing seasons, namely; early (march July) and late (August-November), (Oyewale et al., 2014). Nigeria is the largest producer of cowpea, producing 2.2 million metric tons of dried grain in 2010 (CGIAR, 2014), and harvests 4.5 million ha annually (IITA, 2014). Of the world total production of 10,500,000 tonnes in 1974, about $80 \%$ comes from Nigeria alone (Kochhar, 1986). Niger is the second largest producer, followed by Burkina-Faso, Myanmar, Cameroon and Mali (CGIAR, undated). The crop is produced mostly in the Northern parts of the country (Nigeria) (Omolehin et al., 2007).

\subsection{Economic Significance of Cowpea}

Cowpea production and processing is propelling a silent revolution in Nigeria, as incomes from the crop improve rural livelihoods. Cowpea farmers using improved cowpea varieties and management practices have seen their incomes increase by an average 55\% (CGIAR, 2014). An estimated 38 million households (194 million people) grow cowpea in Sub-Saharan Africa (CGIAR, 2014). Cowpea is the second most important food grain legume crop in tropical Africa (SG 2000, 2010). Cowpea's high protein content, its adaptability to different types of soil and inter cropping systems, its resistance to drought, and its ability to improve soil fertility and prevent erosion makes it an important economic crop in many developing regions (IITA, 2014). 52\% of Africa's production is used for food, $13 \%$ as animal feed, $10 \%$ is wasted (IITA, 2014).

\subsection{Constraints and Problems Involved in Insecticides Application}

Excessive use of chemical insecticides leads to pesticide resistant insects, appearance of secondary pests, and the problems caused by insecticide residues as experienced more especially during 1940-1960 periods in Europe and the U.S.A. (Dent, 1993). Furthermore, chemical sprays, apart from resistance the pests develop, marginally add up to production cost. Chemical sprays also pose danger as only $1 \%$ of the active ingredients reach the pest, while the remaining $99 \%$ of these 
substances, some of which are highly toxic, burden the environment (Daxl et al., 1994). Apart from the above, pesticides threaten human health especially users and consumers of treated food (Kennedy, 1975).

Cowpea farmers rely on chemical insecticides for pest control as a single strategy. But constant use of insecticides leads to problems. These problems include: pesticide treadmill and pest resistance (Palm et al., 1971); creation of secondary pests as happened in Indonesia in 1985-86 with an unprecedented outbreaks of brown plant hopper after high pesticide use (De Fliert and Winarto, 2006); health risk to people as reported by World Health Organization (WHO) in 2003 that an estimate of a million people were poisoned annually, with 20,000 cases resulting in death due to toxicity of the pesticides (Matthews et al., 2003). Another report by WHO in 2002 was that 3 million cases of severe pesticides poisoning which occurred each year with 220,000 fatalities. International labour organization (ILO) in 2002 revealed that 340,000 people died each year from toxic chemical poisoning at their place of work (Kolke and Kern, 2006).

Above all, highly toxic pesticides are associated with suicides, nervous system and mental health problems (Sherwood et al., 2007). To worsen the situation, the chemical pesticides are costly and around $30 \%$ of the agro-chemicals marketed in developing countries do not meet international standards and the products are repeatedly applied at the wrong time, in the wrong dosages or to control the wrong pests (Schuler, 2006), and used by farmers who lacked the technical knowledge and proper skills in applying and handling them.

Current global losses in crop production due to pests are of the order of US $\$ 300$ billion annually, and the estimated expenditure by international development agencies on pest control projects in 1988 was at least US \$150 million (Rothschild, 1992). In view of the above, Cowpea pest incidence and diversity dictate that a single control strategy is unlikely to produce satisfactory results. Even when chemical control strategies are used, the pests response differently to the different insecticides. As a result, the "best mix" approach is currently advocated rather than those control problems that utilize single strategies whose adhoc activities result in insect pest outbreaks. In order to choose an effective pesticide for control of any insect pest, the feeding habit of the insect must be known. Chewing insects are easily controlled by spraying with insecticides, while sucking insects are more difficult to control except with contact or systemic insecticides. Before using insecticides, experts should be consulted on the choice of the appropriate insecticide for the insect pest to be controlled, the toxic level of the insecticide chosen, correct method of use and the protective precautions to be adopted by the user (Opeke, 2006).

It is therefore advisable that Governments at all levels to adopt Article 3.1 of the United Nations food and Agriculture Organization which established voluntary standards for all public and private organizations engaged in the distribution and use of pesticides. The code stipulated that governments have overall responsibility and powers to regulate the distribution and use of pesticides in their countries. Such regulations are normally included in the food and drug Acts of each country of West Africa (Opeke, 2006). However, as a matter of public importance, this article should be enforced in earnest in order to achieve ideal desires for the use of pesticides. 


\subsection{Diffusion and Adoption of Agricultural Innovations}

Throughout sub-Saharan Africa, there is a growing consensus that inadequate systems and methods of technology transfer have limited rapid and broad-based dissemination and adoption of many improved agricultural technologies (Singh and Rachie, 1985). This has led to a search for and experimentation with alternative methods of technology designed dissemination. In the 1980s, participatory agricultural research (PAR) emerged as an attempt to enhance technology suitability and transfer by engaging farmers in the research process. Previous research in the diffusion of agricultural innovations asserts that awareness and knowledge of a new technology is a necessary first step in the adoption, decision-making process (Ogunbameru, 2001).

In practical terms, diffusion is the process by which a new idea or practice is communicated or transferred from its source of invention or development to the ultimate adopters (Ogunbameru, 2001). Diffusion begins with the actual entry of an innovation into a target system. However, the active diffusion requires a more technical approach and communication techniques in the diffusion of innovations, the process of attention, interest, desire, conviction and action are involved (Ani, 2007). The extension agent, in this wise, represents the source of information and this requires him or her to have a thorough knowledge of the farm innovation from the onset. With professionalism, the extension agent understudies the target system and thereby determines the appropriate entry point. The entry point may be an individual, a group or any other medium. The appropriateness will be determined by the following criteria (Ani, 2007):-

1) The popularity and thus representativeness among the group thereby providing legitimation for information.

2) Availability and readiness to serve in the required way

3) Personal disposition towards change in general and the technology specifically.

However, all sources of information are now accessible by everyone including the target systems. The issue of concern now then becomes information management on the part of extension service providers. This entails managing whatever information the target audience accesses and help bring out values or worthlessness of the information. The extension service providers are required to be aware of all information and help the target system sort out the area that are beneficial and that would offer the best results (Ani, 2007).

It is in view of the above that all tiers of government in Nigeria including FCT Abuja established ministries/departments of agriculture to plan/organize agricultural policies and programmes, more especially, state governments established Agricultural Development Programmes (ADPs) to implement their extension services for effective and efficient agricultural development. The ADPs has good network of extension deliveries in reaching the targeted farmers at all levels.

The spread of agricultural technology (diffusion) generally will be influenced by the characteristics of farmers in the community. For instance, farmers differ in their willingness to know or learn about, adopt and use fertilizers. This has been described as their level of innovativeness. This is usually affected by educational level, income status, participation in community activities etc. recognition and patronage of contact farmers and community local leaders can synergize efficient diffusion of agricultural innovations. 
The adoption process is a mental process which an individual goes through from first hearing about a new idea to the complete and full incorporation of the idea into the total system of his behaviours. The process of adopting and using innovations among farmers is a complex one which involves a sequence of thoughts and actions (Ani, 2007). An innovation can be a new product, equipment, skill, practice or idea related to solving identified farmers' production constraints. Innovation should therefore be seen as "changes to the status quo" which is considered to be a better solution of existing problems (Ogunbameru, 2001).

\subsection{Factors Affecting Adoption of Innovations}

It is a presumption that farmers will adopt any improved and proven agricultural innovation an extension staff communicates to them. Experience has shown, however, that this is far from being true (Ogunbameru, 2001). In addition to meeting the farmers' interests, needs and aspirations, the extension staff must ensure that the new innovation they introduce to the farmers meet the following conditions:

1) The new practice, package, knowledge, technology does not increase farmers' risks. Farmers generally avert risk whenever possible. Therefore, the lesser the risk involved in the innovation, the greater its adoption by the farmers.

2) The new technology does not depart radically from the current practices of the farmers. Consequently, the innovation must be easily learned and understood by the farmers.

3) The potential gains, i.e. the cost-benefit, from the adoption of the improve technology must exceed the added costs.

4) All the needed inputs and associated services involved with the new practice or technology must be readily obtainable and affordable by the farmers.

5) The innovation must conform to the norms, values and cultures of the people.

6) There must be a ready market for the produce obtained by the farmers after adopting the new technology.

7) The new practice or technology must be thoroughly tested in the target area where it is to be introduced for the following reasons:-

- To ascertain that the new technology is adaptable to the local conditions.

- To instill confidence into the extension staff that the technology will work in the local environment and that it has some relative advantage over the existing farmers' practice.

- To arouse farmers' interest and extension workers' credibility. Essentially, the technology must be appropriate, relevant, affordable and within the absorption and managerial capacity of the individual ultimate users.

The new technology or package will be likely accepted if it meets existing personality needs and drives; if it is in harmony with group norms and loyalties; and if the source is perceived as trust worthy or as an expert (Ogunbameru, 2001).

\subsection{Sources of Technical Information}

Rural people, particularly farmers obtain information from many sources. The sources are generally categorized into four, namely; mass media, Government agencies, neighbors and friends and commercial sources. 
Research has shown that sources most by farmers vary with the stages in the adoption of diffusion process as indicated below:-

2.7.1. Mass Media: are most important in creating awareness and interest. The mass media include: radio, television, newspapers. Radio plays an important role in all the five stages of the adoption process. It reinforces the determination of listener.

2.7.2. Friends and Neighbours: are first important in the evaluation, trial and adoption stages. Similarly, friends and neighbors rank second as important source for awareness and interest.

2.7.3. Commercial Sources: the use of satellite, video and computer technologies are very expensive but effective in providing farmers with on-line access to relevant agricultural information from established databases or to agricultural specialists responding to transmitted questions via telephone line. Presently, both the extension services and other service providers and their clients are experimenting with newer digital opportunities that can be effectively used to exchange, process, manage and communicate information (Ani, 2007). News prints also play a significant role under commercial dispensation.

2.7.4. Government Agencies: Such as ministries and departments of agriculture, ADPs, Universities, Colleges and Research Centers and Extension Agencies etc. are also important source of information at evaluation, trial and adoption stages.

\subsection{Factors Affecting the Use of Insecticides by Cowpea Farmers}

Chemical pest control is now a dominant strategy being used by farmers in many African countries (Williamson et al., 2008). Tijani and Oshotimehin (2007) posited that pesticides are protective resources which are unique and differ from other productive resources. This is because they do not affect productivity directly but are applied to eliminate those factors that directly reduce productivity. For a good result in cowpea production, pest control is a major task. A socioeconomic assessment of pesticide use among cowpea farmers in Ibarapa East Local Government Area of Oyo State was carried out by Tijjani (2003). The study used logit regression to identify the factors that influence the use of pesticides by cowpea farmers. The result of the study showed that, age, farming experience and income positively affect the use of pesticides by the respondents. Omelehin et al. (2007) used probit analysis to ascertain the factors that influence the adoption the of chemical pest control by cowpea farmers in Makarfi Local Government Area of Kaduna State, Nigeria. The result of the study revealed that, adoption of chemical pest control is influenced by age of the farmer, marital status, educational attainment, desire for higher yield and contact with extension service. Similarly, Kedebe et al. (1990) reported that family size play a vital role in adoption of any particular farm practices or technologies.

\subsection{Conceptual Framework}

The conceptual framework in figure 1 is designed to analyse specifically the socio-economic factors influencing the use of insecticides. The major concepts include; socio-economic 
characteristics, factors affecting the use of insecticides, source of technical information, problems involved in insecticides application, common insecticides used, cost of insecticides and constraints encountered by cowpea farmers. However, the purpose of conceptual framework in this study is to clarify concepts and propose relationships among the concepts in the study and to also provide a context for interpreting the study findings, explain observation and to encourage theory development that is useful to practice.

The framework presupposes that personal characteristics of cowpea farmers can influence the use of insecticides, and also directly affect their productivity either low, high of moderate. Furthermore, some of these personal characteristics such as gender, age, marital status, family size, level of education, major occupation, years of experience, farm size and number of extension contacts can facilitate and influence the use of insecticides and make the cowpea farmers form attitude either favourable or unfavourable towards the use of insecticides.

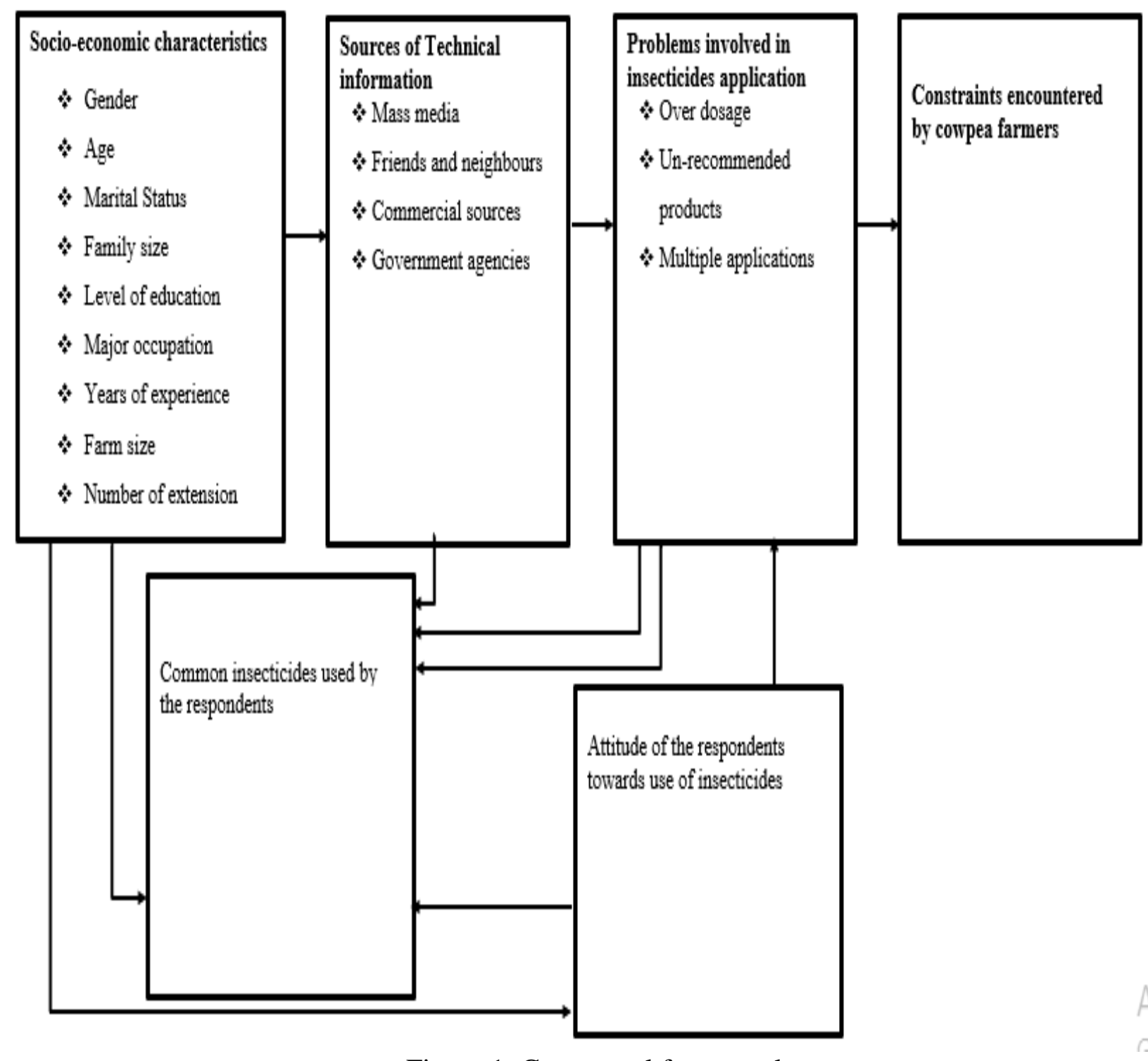

Figure 1: Conceptual framework 


\section{Methodology}

\subsection{Study Area}

Fufore Local Government is one of the 21 Local Government Areas (LGAs) of Adamawa State (Figure 1). Fufore LGA was created in 1976 and one of the largest LGAs of the State. Fufore, is the headquarters of Fufore Local Government, and 26km away from Yola, the Capital of Adamawa State. Fufore is situated South-East of Girei, and lies between latitude 9013' North and longitude 12039' East (Fufore LGA at a Glance, 2013). The LGA shares boundary with Jada LGA in the South, Mayo-belwa LGA in the South-West, Yola South LGA in the West, Girei LGA in the North-West Song LGA in the North, Maiha LGA in the North-East and Cameroun Republic in the East. The LGA has a total land area of about 3,666Sqkm (Ba et al., 2014). Fufore LGA comprised of eleven (11) political wards, namely: Beti, Farang, Fufore, Gurin, Karlahi, Mayo-ine, Pariya, Ribadu, Uki-tuki, Wuro-bokki and Yadim, respectively. The average annual rainfall recorded in the area is between 750-1000mm (Ba et al., 2014). The rainy season starts from April and end in October. The rainfall in this area is monomodal. The temperature varies with warm day time and cool night time temperatures. The temperature is warmer between the months of March to June. The mean annual temperature varies between 300c-420c (Ba et al., 2014). The area experiences distinct dry and wet seasons with temperature and humidity varying with season. The dry season period is between December and March, and characterized by dry, dusty and hazy north - east trade winds that blow over the area from Sahara Desert (Ba et al., 2014).

According to 2006 population census, Fufore LGA has a population of 207,287 people which is projected to be 246,683 by 2012 (Ba et al., 2014). The major occupation of the people is farming (which include: crop production, livestock husbandry, vegetables/irrigation farming and fishing). Crops such as maize, sorghum, millet groundnuts, bambara groundnut, cowpea, root and tuber crops, and tree crops are grown in the area. Livestock such as cattle, sheep and goats, and poultry are produced in the area. Local trading such as crop processing, cattle and small ruminants fattening and trading to a lesser extent also form their occupation. The major tribes found in the LGA includes: Batta, Fulani, Hausa and Verre, while Chamba, Kanuri, Laka are among few others. Fulfulde (Fulani language) is the most widely spoken language followed by Hausa.

\subsection{Sources and Type of Data}

Data for this research were obtained from primary source with the aid of questionnaires administered to the respondents and interview schedule where respondents cannot read or write. Data on socio-economic variables such as: Age, Gender, Marital status, family size, major occupation, years of experience in farming, farm size and number of extension visits by workers, types of insecticides and cost, etc. were collected for analysis in order to achieve the study objectives. 


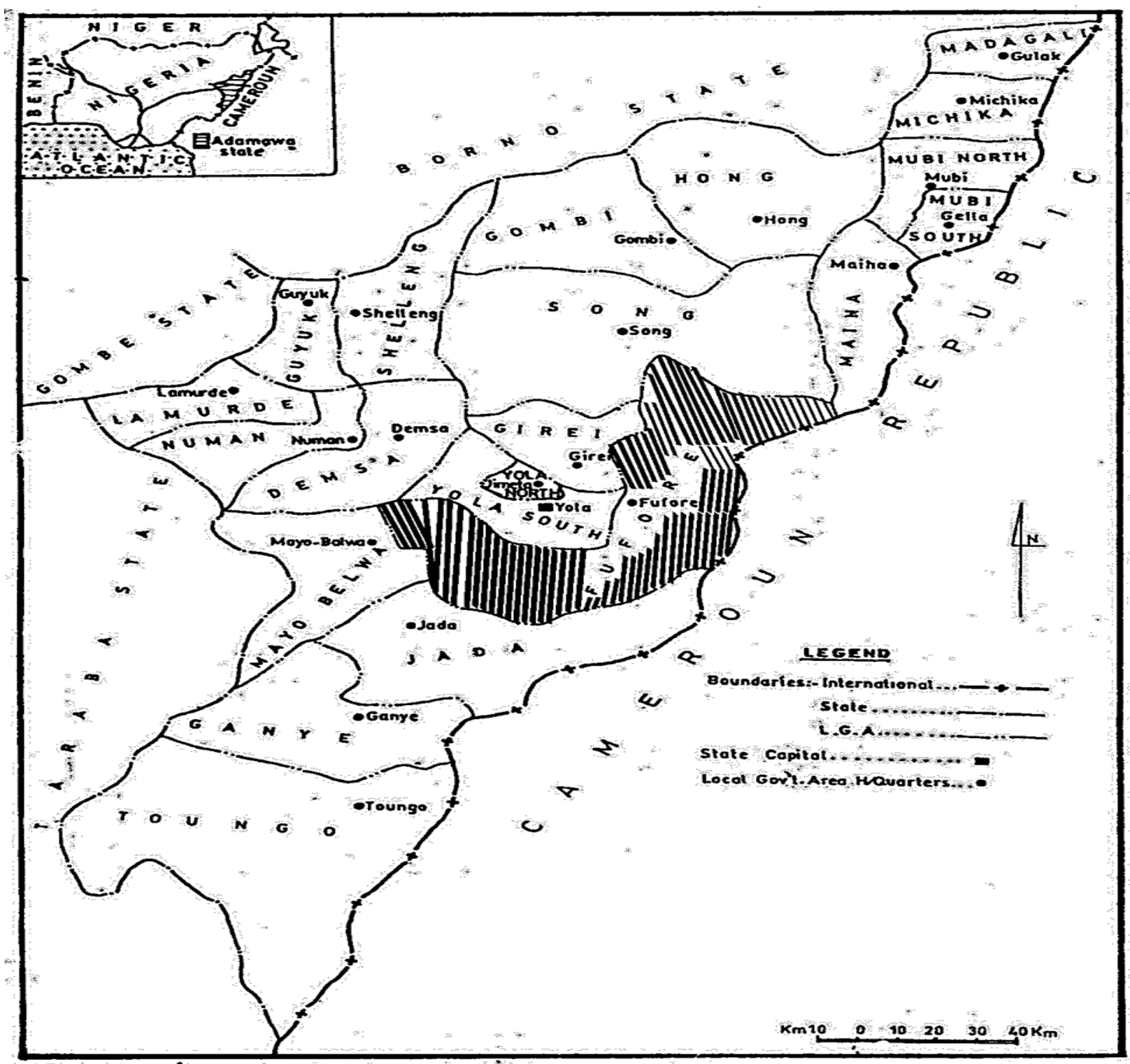

Figure 2: Map of Adamawa State showing the Study Area

Source: Adebayo and Tukur, 1999

\subsection{Sampling Techniques}

Multi-stage sampling procedure was used to select respondents for the study. Step one involved purposive sampling. Step two employed random sampling. Step three, proportionate approached. Step one involved a purposive selection of 6 out of 11 wards based on their prominence in Cowpea production. Step two employed Random Sampling of two villages from each of the 6 wards to identify cowpea farmers, while in step three; purposive sampling based on insecticides usage (refer table 1). The respondents were drawn in proportion to the population of cowpea growers that are using insecticides in each village. 


\subsection{Sample Frame/Population of the Study}

The sample frame is registered cowpea farmers in Fufore Local Government Area of Adamawa State. 210 respondents were used for the research.

\subsection{Methods of Data Analysis}

In order to achieve the research objectives, descriptive statistics such as means, percentages and frequency distribution were used to analyze the data and achieve objectives i, ii, iv and v.

Multiple regression analysis was used to determine the socio-economic factors influencing the application of insecticides for control of Cowpea pests among farmers in the study area to achieve objective iii. The regression equation is expressed as:

$\begin{array}{lll}\mathrm{Y}=\beta 0+\beta 1 \mathrm{X} 1-\beta 2 \mathrm{X} 2+\beta 3 \mathrm{X} 3+\beta 4 \mathrm{X} 4+\beta 5 \mathrm{X} 5+\beta 6 \mathrm{X} 6+\mu \\ \text { Where: } & = & \text { Quantity of insecticides applied (litres) } \\ \mathrm{Y} & = & \text { Independent variables } \\ \mathrm{X} 1 \text { to } \mathrm{x} 6 & = & \text { Regression constant } \\ \beta 0 & = & \text { Gender }(1=\text { male, } 0=\text { female) } \\ \mathrm{X} 1 & = & \text { Age (years) } \\ \mathrm{X} 2 & = & \text { Family size (number of people) } \\ \mathrm{X} 3 & \neg= & \text { Level of education (years spent in school) } \\ \mathrm{X} 4 & = & \text { Years of experience in farming (years) } \\ \mathrm{X} 5 & = & \text { Farm size (hectares) } \\ \mathrm{X} 6 & = & \text { Error term } \\ \mu & & \end{array}$

Table 1: Selection of Respondents

\begin{tabular}{|l|l|l|c|c|}
\hline S/No. & Ward & Village & Number of Cowpea farmers & $\begin{array}{l}\text { Number of } \\
\text { Respondents }\end{array}$ \\
\hline $\mathbf{1}$ & Karlahi & Karlahi-Gari & 65 & 5 \\
& & Ngarawo-Verere & 50 & 4 \\
\hline $\mathbf{2}$ & Beti & Chigari & 300 & 24 \\
& & Gawi & 35 & 3 \\
\hline $\mathbf{3}$ & Gurin & Gurin & 150 & 12 \\
& & Wuro-Yolde & 50 & 4 \\
\hline $\mathbf{4}$ & Wuro-Bokki & Malabu-Gari & 1000 & 79 \\
& & Wuro-Bokki & 100 & 8 \\
\hline $\mathbf{5}$ & Farang & Farang & 120 & 9 \\
& & Mubako & 500 & 20 \\
\hline $\mathbf{6}$ & Fufore & Fufore & 250 & 3 \\
\hline Total & 6 & Solomsi & 40 & 210 \\
\hline
\end{tabular}

Source: Field survey, 2015. 


\section{Results and Discussions}

\subsection{Socio-economic Characteristics of the Respondents}

This section describes the socio-economic characteristics of the respondents. The variables considered were; age, sex, marital status, family size, level of education, major occupation, farming experience, farm size and number of extension contacts. This corroborate with a view by Omolehin (2007) that the probability that a farmer adopts chemical pest control in Cowpea Production is a function of his age, marital status, family size, educational qualification, extension contacts, his expectation of higher yield, and his expectation of clean seed production, and his membership of farmers' association.

\subsubsection{Age Distribution of the Respondents}

Result in Table 2 shows age distribution of the respondents, $1.43 \%$ were less than 20 years, $11.43 \%$ were between 20-29 years, $26.67 \%$ were between $30-39$ years, $29.05 \%$ (majority) were between 40-49 years, $24.28 \%$ were between $50-59$ years and $7.14 \%$ were $60 y e a r s$ and above. This implies that, majority of the respondents were within productive middle age of 40-49 years.

\subsubsection{Sex Distribution of the Respondents}

Sex distribution of the respondents was presented in table 3. It indicates that $84.76 \%$ were male and $15.24 \%$ were female. This shows that majority of Cowpea Farmers in the study area that use insecticides were male. This could be as a result of purdah practiced in the study area which is predominantly Muslims.

Table 2: Age Distribution of the Respondents

\begin{tabular}{|l|c|c|}
\hline Age (Years) & Frequency & Percentage (\%) \\
\hline$<\mathbf{2 0}$ & 3 & 1.43 \\
\hline $\mathbf{2 0 - 2 9}$ & 24 & 11.43 \\
\hline $\mathbf{3 0 - 3 9}$ & 56 & 26.67 \\
\hline $\mathbf{4 0 - 4 9}$ & 61 & 29.05 \\
\hline $\mathbf{5 0 - 5 9}$ & 51 & 24.28 \\
\hline $\mathbf{6 0}$ and above & 15 & 7.14 \\
\hline Total & 210 & 100 \\
\hline Mean & & \\
\hline
\end{tabular}

Source: Field Survey, 2015.

Table 3: Sex Distribution of the Respondents

\begin{tabular}{|l|c|c|}
\hline Gender & Frequency & Percentage (\%) \\
\hline Male & 178 & 84.76 \\
\hline Female & 32 & 15.24 \\
\hline Total & 210 & 100 \\
\hline
\end{tabular}

Source: Field Survey, 2015. 


\subsubsection{Marital Status of the Respondents}

Marital status of the respondents shows that $90.48 \%$ were married, $7.62 \%$ were single and $1.90 \%$ were Widows (Table 4). This implies that majority of the respondents were married because of the value attached to marriage in the study area, and married individuals were more saddled with sourcing for food and income than singles. The finding corresponds with the view of Omolehin (2007) who revealed that married farmers are more conscious of the need to get better yields so that they could meet their family food needs as well as having marketable surplus to generate income for family financial needs and hence married farmers are better adopters of chemical pest control for cowpea production (Omolehin, 2007).

\subsubsection{Family Size of the Respondents}

The large family size is required to satisfy the farm labour requirement in the study area. Table 5 shows that $20 \%$ have between 1-5 as members of their household, $32.86 \%$ between $6-10,27.62 \%$ were $11-15,10.95 \%$ were $16-20$ and only $8.57 \%$ have above 20 people as members of their household. This implies that majority of the respondents $(32.86 \%)$ have moderate family size of 6-10 which serves as an advantage in providing family labour for various farm operations.

\subsubsection{Level of Education of the Respondents}

The educational level of the respondents is a key factor in decision making to improve farming practices, and as a guide in interpreting the instructions on insecticides' as recommended by the manufacturers about their applications. Table 6 shows that $43.33 \%$ had no formal education, $16.67 \%$ had primary education, $27.62 \%$ has secondary education, $3.33 \%$ had certificate and NCE $3.81 \%$, OND $2.86 \%$, HND $1.43 \%$ and Degree $0.95 \%$. This implies that most $(56.67 \%)$ of the respondents had one form of Formal education or another.

As suggested by Omolehin (2007), the higher the level of education of a farmer, the more likely for the farmers to adopt yield increasing productivity method like chemical pest control in Cowpea Production.

\subsubsection{Major Occupation of the Respondents}

Table 7 shows the major occupation of the respondents in the study area. It revealed that $73.81 \%$ has farming as primary occupation, $13.81 \%$ were traders, $2.86 \%$ were artisans and $9.52 \%$ were civil servants. This indicates that majority of respondents in the study area were engaged in one form of farming or another.

Table 4: Marital Status of the respondents

\begin{tabular}{|l|c|c|}
\hline Marital Status & Frequency & Percentage (\%) \\
\hline Married & 190 & 90.48 \\
\hline Single & 16 & 7.62 \\
\hline Widowed & 4 & 1.90 \\
\hline Total & 210 & 100 \\
\hline
\end{tabular}

Source: Field Survey, 2015. 
Table 5: Distribution of family size of the Respondents

\begin{tabular}{|l|c|c|}
\hline Family size (Persons) & Frequency & Percentage (\%) \\
\hline $\mathbf{1 - 5}$ & 42 & 20 \\
\hline $\mathbf{6 - 1 0}$ & 69 & 32.86 \\
\hline $\mathbf{1 1 - 1 5}$ & 58 & 27.62 \\
\hline $\mathbf{1 6 - 2 0}$ & 23 & 10.95 \\
\hline Above 20 & 18 & 8.57 \\
\hline Total & 210 & 100 \\
\hline Mean & & \\
\hline
\end{tabular}

Source: Field Survey, 2015.

Table 6: Educational Level Distribution of the Respondents

\begin{tabular}{|l|c|c|}
\hline Level of education & Frequency & Percentage (\%) \\
\hline Non-formal & 91 & 43.33 \\
\hline Primary education & 35 & 16.67 \\
\hline Secondary education & 58 & 27.62 \\
\hline Certificate & 7 & 3.33 \\
\hline NCE & 8 & 3.81 \\
\hline OND & 6 & 2.86 \\
\hline HND & 3 & 1.43 \\
\hline Degree & 2 & 0.95 \\
\hline Total & 210 & 100 \\
\hline
\end{tabular}

Source: Field Survey, 2015.

Table 7: Distribution of Respondents according to major occupation

\begin{tabular}{|l|c|c|}
\hline Major Occupation & Frequency & Percentage (\%) \\
\hline Farming & 155 & 73.81 \\
\hline Trading & 29 & 13.81 \\
\hline Artisan & 6 & 2.86 \\
\hline Civil Service & 20 & 9.52 \\
\hline Total & 210 & 100 \\
\hline
\end{tabular}

Source: Field Survey, 2015.

\subsubsection{Respondents Years of Experience in Cowpea Farming}

Table 8 reveals the farming experience of the respondents. $23.33 \%$ respondents had $1-5$ years experience, $36.19 \%$ had 6-10 years experience, $19.05 \%$ had $11-15$ years experience, $12.36 \%$ had 16-20 years experience and $8.57 \%$ had over 21 years farming experience. This indicate that majority (36.19\%) of the respondents had 6-10 years experience in Cowpea Production which translates that most of cowpea farmers that use insecticides lacks much experience in farming and will lead to reduction in cowpea production that may result to reduction in income to the farmers and proteins source. While the youngest and eldest categories were of the same number. The age is significant in accepting improved farming technologies as corroborated that the age has direct relationship with experience especially in rural farming communities and capable of handling and applying insecticides effectively and promptly. 


\subsubsection{Farm Size of the Respondents}

The land area put under Cowpea Production varies among the respondents due to variation of income aspiration and accessibility to farmland. Table 9 shows that $56.19 \%$ had 1-2.5 hectares, $35.71 \%$ had 3-5 hectares, 3.81\% had 6-8 hectares and $4.29 \%$ had 10 hectares and above. This shows that majority of the respondents had 1-2.5 hectares due to subsistence nature or noncommercialization of farming.

\subsubsection{Number of Extension Contacts of the Respondents for the Growing Season}

Table 10 reveals that $90 \%$ of the respondents had no extension contact, while $10 \%$ had extension contacts. This indicates that, there is inadequate extension services in the study area. Extension contact is very necessary for improvement of farming, especially, use of insecticides in cowpea production as corroborated by Omolehin (2007) that, extension contact was found to be significant and this shows that farmers having regular contact with extension agents are more knowledgeable about the advantages of using chemical pest control in cowpea production and are consequently better adopters of this production practice.

Table 8: Distribution of respondents according to farming experience.

\begin{tabular}{|c|c|c|}
\hline Farming experience (years) & Frequency & Percentage (\%) \\
\hline $\mathbf{1 - 5}$ & 49 & 23.33 \\
\hline $\mathbf{6 - 1 0}$ & 76 & 36.19 \\
\hline $\mathbf{1 1 - 1 5}$ & 40 & 19.05 \\
\hline $\mathbf{1 6 - 2 0}$ & 27 & 12.86 \\
\hline above 20 & 18 & 8.57 \\
\hline Total & 210 & 100 \\
\hline
\end{tabular}

Source: Field Survey, 2015.

Table 9: Distribution of Respondents according to Farm size.

\begin{tabular}{|c|c|c|}
\hline Farm size (ha) & Frequency & Percentage (\%) \\
\hline $\mathbf{1 - 2 . 5}$ & 118 & 56.19 \\
\hline $\mathbf{3 - 5}$ & 75 & 35.71 \\
\hline $\mathbf{6 - 8}$ & 8 & 3.81 \\
\hline $\mathbf{1 0}$ and above & 9 & 4.29 \\
\hline Total & 210 & 100 \\
\hline
\end{tabular}

Source: Field Survey, 2015.

Table 10: Distribution of Respondents according to Extension Contacts

\begin{tabular}{|l|c|c|}
\hline Extension contacts & Frequency & Percentage (\%) \\
\hline Yes & 21 & 10 \\
\hline No & 189 & 90 \\
\hline Total & 210 & 100 \\
\hline
\end{tabular}

Source: Field Survey, 2015. 


\subsection{Insecticides used by the Respondents in the Study Area}

The entire respondents (100\%) used modern insecticides in controlling cowpea pests in the study area. The insecticides carries different chemical ingredients as well as trade names. The insecticides acts in form of contact poison, stomach poison, systemic or repellent. The insecticides kills different types and species of insect pests at various stages of cowpea growth. The cowpea farmers dissolve the insecticides by mixing with water in spray tank at required proportion and then spray.

However, there is multiple responses in the use of the insecticides. Table 11 below shows details of insecticides used by respondents in the study area.

\subsubsection{Frequency of Insecticides Application}

Various Scholars and Research Institutes recommend the desired insecticides for control of cowpea pests, number of applications, application dosages and application intervals per production cycle, etc. The research revealed that, $21.43 \%$ had $1-3$ times, $45.24 \%$ (majority) had 4-6 times, $17.62 \%$ had $7-9$ times, $11.90 \%$ had $10-12$ times, and $3.81 \%$ had above 12 . This implies that most of the respondents had multiple applications which may lead to insecticide treadmill, health hazard to the farmers, appearance of secondary pests and pests resistance. Refer Table 12 below for details.

Table 11: Distribution of respondents according to insecticides used

\begin{tabular}{|l|c|c|}
\hline Insecticides & *Frequency & Rate (\%) \\
\hline Lambda-Cyhalothrin 2.5\%Ec & 96 & 45.71 \\
\hline Cypermethrin 10Ec or 10\%Ec & 159 & 75.71 \\
\hline Acetamiprid & 17 & 8.10 \\
\hline Chlorpyriphos 20Ec or 20\%Ec & 7 & 3.33 \\
\hline Emamectine Benzoate & 6 & 2.86 \\
\hline Profenofos 40\% + Cypermethrin 4\% Ec & 7 & 3.33 \\
\hline Emacot 019Ec & 1 & 0.48 \\
\hline Dimethoate + Lambda-Cyhalothrin & 10 & 4.76 \\
\hline Magic plus & 18 & 8.57 \\
\hline Action 40 & 2 & 0.95 \\
\hline Rocket & 1 & 0.95 \\
\hline Cypercot & 2 & 0.48 \\
\hline Cypercal & 1 & 0.95 \\
\hline Kurakurin & 3 & 0.48 \\
\hline Cyperforce & 1 & 1.43 \\
\hline Uppercot & 1 & 0.48 \\
\hline Landrin & 1 & 0.48 \\
\hline Mask 100EC & 1 & 0.48 \\
\hline Attacker & 1 & 1.43 \\
\hline Imacot & 1 & 0.48 \\
\hline Kombat & & 1.43 \\
\hline
\end{tabular}




\begin{tabular}{|l|l|l|}
\hline No-go & 1 & 0.48 \\
\hline Monocrotophos & 1 & 0.48 \\
\hline Suraksha & 1 & 0.48 \\
\hline Promethrin & 1 & 0.48 \\
\hline Dichlorovinyl dimethyl phosphate & 6 & 2.86 \\
\hline Monocol & 4 & 1.90 \\
\hline
\end{tabular}

Source: Field survey, 2015. *Multiple responses

Table 12: Distribution of respondents according to frequency of insecticides application.

\begin{tabular}{|c|c|c|}
\hline Number of applications & Frequency & Percentage (\%) \\
\hline $\mathbf{1 - 3}$ & 45 & 21.43 \\
\hline $\mathbf{4 - 6}$ & 95 & 45.24 \\
\hline $\mathbf{7 - 9}$ & 37 & 17.62 \\
\hline $\mathbf{1 0 - 1 2}$ & 25 & 11.90 \\
\hline above 12 & 8 & 3.81 \\
\hline Total & 210 & 100 \\
\hline
\end{tabular}

Source: Field Survey, 2015.

\subsection{Factors Influencing Application of Insecticides to Control Cowpea Pests}

The multiple regression model (Linear function) was used to identify the factors that influences the application of insecticides in the study area has a good fit prediction having an F-statistic of 40.57 which is significant at $1 \%$ level. Similarly, the coefficient of determination R-square was 0.545 , which implies that about $55 \%$ of the variability in the use of insecticides is explained by the independent variables used in the model. The result of the analysis as contained in Table 13 revealed that, age of the farmer X2 (-0.003066), household size X3 (0.004386), educational attainment of the farmer X4ᄀ $(0.014115)$, farming experience of the respondent X5 $(0.008612)$ and farm size of the respondent X6 (0.036816) were all significant at 1\%, 5\% and $10 \%$ respectively.

The finding reveals that, age of the farmer (X2) has an indirect relationship with the use of insecticides to control cowpea pests in the area having a coefficient of 0.05 (significant at $5 \%$ ). This implies that, as farmer grow older the less the use of insecticide. This finding is in line with the report of Tijjani (2003), but contradicts that of Omelehin et al. (2007) who reported a direct relationship between the adoption of chemical pest control and age of the cowpea farmer. Household size (X3) was positive and statistically significant at $10 \%$ level. This shows that, household size directly affects the application of insecticides by the respondents. This result validate the claim made by Kebede et al. (1990) that increase in household size may influence the adoption of improved technologies that will improve yield and income of the family.

Level of education (X4) was positive and statistically significant at $1 \%$ level coefficient of 0.014 . This indicates that, respondents with higher literacy level are better informed, hence they may not hesitate to adopt technologies that will improve their productivity. Similarly, high literacy level is usually related with better income level which will reduce the effect of transition cost which mostly affect the adoption of improved technologies. This result lends credence to those of Omelehin et 
al. (2007) who reported a positive relationship between educational level and the adoption of improved technologies like the use of pesticides by cowpea farmers.

Farming experience of the respondent (X5) has positive and significant effect at $1 \%$ level with the application of insecticides in the area (significant at $1 \%$ level). This connotes that, the higher the farmer's experience, the better his chances of applying insecticides to control pests in the area. This is because, by virtue of their experience they might have tried different technologies and may be in a better position to adopt the better one. This result agrees with the findings of Tijjani (2003) who reported a similar outcome in a study he conducted on socio-economic assessment of pesticide use among cowpea farmers in Ibarapa L.G.A. of Oyo state, Nigeria. Similarly, farm size (X6) positively influence the use of insecticides in the area and the coefficient is significant at $1 \%$ level (having a coefficient of 0.0368). This implies that, increase in farm size will increase the possibility of applying insecticides to cowpea farm and vice versa. This is as expected since with increase in farm size, the farmer may adopt technologies that will minimize the risk of crop failure in order to improve farm output and make maximum gain.

Table 13: Factors Influencing Application of Insecticides to Control Cowpea Pests

\begin{tabular}{|l|c|c|c|}
\hline Variable & Coefficient Std. Errort-Statistic \\
\hline Gender $\left(\mathrm{X}_{1}\right)$ & 0.029142 & 0.035655 & 0.817341 \\
\hline Age $\left(\mathrm{X}_{2}\right)$ & -0.003066 & 0.001252 & $-2.447754^{* *}$ \\
\hline Household Size $\left(\mathrm{X}_{3}\right)$ & 0.004386 & 0.002550 & $1.720112^{* * *}$ \\
\hline Education Level $\left(\mathrm{X}_{4}\right)$ & 0.014115 & 0.002562 & $5.508741^{*}$ \\
\hline Farming Experience $\left(\mathrm{X}_{5}\right)$ & 0.008612 & 0.001862 & $4.625859^{*}$ \\
\hline Farm Size $\left(\mathrm{X}_{6}\right)$ & 0.036816 & 0.004990 & $7.378059^{*}$ \\
\hline Constant & 0.337048 & 0.059169 & $5.696402^{*}$ \\
\hline $\mathrm{R}^{2}$ & 0.545270 & & \\
\hline F-Statistic & $40.56982 *$ & & \\
\hline S.E & 0.194029 & & \\
\hline
\end{tabular}

Source: output from Eviews 7 software *, **, *** Significant at 1, 5 and $10 \%$ respectively

\subsection{Cost of Insecticides Incurred Per Unit Area to Control Cowpea Pests}

The respondents differ in terms of amount expended in procuring insecticides. $41.43 \%$ (majority) of the respondents spent less than N5000/ha, while 29.05\% spent N5001-N10000/ha. Similarly, $11.90 \%$ incurred N10001-15000/ha. Furthermore, 6.67\% spent N15001-N20000, on the other hand, 4.76\% expend N20001-N25000/ha. Apart from the above, 6.19\% procure insecticides for more than $\mathrm{N} 25000 / \mathrm{ha}$.

The average cost of insecticides incurred in producing a hectare of cowpea in the study area within the research period is $\mathrm{N} 3,737.17$. Table 14 shows details on cost of insecticides incurred during the study period. 


\subsubsection{Application Interval of Insecticides in the Study Area}

The respondents differ on interval of insecticides application. 51.43\% (majority) applied insecticides every 7 days. $42.38 \%$ applied in less than 7 days, $4.76 \%$ applied every 10 days, while $1.43 \%$ applied every 14 days, respectively. Refer table 15 for details.

Table 14: Distribution of respondents according to cost of Insecticides per unit area (ha).

Source: Field Survey, 2015.

\begin{tabular}{|l|c|c|}
\hline Cost (A) & Frequency & Percentage (\%) \\
\hline$<\mathbf{5 0 0 0}$ & 87 & 41.43 \\
\hline $\mathbf{5 0 0 1 - 1 0 0 0 0}$ & 61 & 29.05 \\
\hline $\mathbf{1 0 0 0 1 - 1 5 0 0 0}$ & 25 & 11.90 \\
\hline $\mathbf{1 5 0 0 1 - 2 0 0 0 0}$ & 14 & 6.67 \\
\hline $\mathbf{2 0 0 0 1 - 2 5 0 0 0}$ & 10 & 4.76 \\
\hline$>\mathbf{2 5 0 0 0}$ & 13 & 6.19 \\
\hline Total & 210 & 100 \\
\hline
\end{tabular}

Table 15: Distribution of respondents according to Insecticides application interval

\begin{tabular}{|l|c|c|}
\hline Application interval & Frequency & Percentage (\%) \\
\hline$<$ 7 days & 89 & 42.38 \\
\hline 7 days & 108 & 51.43 \\
\hline 10 days & 10 & 4.76 \\
\hline 14 days & 3 & 1.43 \\
\hline Total & 210 & 100 \\
\hline
\end{tabular}

Source: Field Survey, 2015.

\subsection{Constraints Encountered by Cowpea Farmers in the Study Area}

The research result revealed various constraints encountered by respondents in the study area with regards to cowpea production activities as shown on Table 16. The constraints experienced were multiple as differences occurred from one respondent to the other. The constraints are in the form of technical, economic, social, climatic, political, etc.

Problem of insect pests alone account for $65.71 \%$, while weak extension services is responsible for $15.24 \%$. High cost of inputs is responsible for $40 \%$, scarcity of inputs $37.14 \%$, difficulty in accessing farmland $4.28 \%$, poor capital base $27.62 \%$, difficulty to access credit $31.90 \%$, malicious damage of crops by pastoralists $24.28 \%$, in-security $5.24 \%$, poor storage facilities $22.38 \%$, and low market value $19.52 \%$. Others include, problem of mobility $5.24 \%$, problem of parasitic weeds $5.24 \%$, farm traction and human drudgery $3.33 \%$ and abnormal seasonal changes $2.38 \%$. Furthermore, high weeds density $0.95 \%$ inadequate labour $2.38 \%$ and marketing $1.43 \%$.

This indicates that, most of the problems encountered by cowpea farmers were insect pests, scarcity and high cost of inputs, difficulty to access credit and poor capital base, poor storage facilities and malicious damage by pastoralists, and weak extension services among others. 
Table 16: Distribution of Cowpea farmers according to Constraints encountered in the study area $(\mathrm{N}=210)$

\begin{tabular}{|l|c|c|}
\hline Constraints & *Frequency & Percentage \\
\hline Insect pests & 138 & 65.71 \\
\hline Weak extension services & 32 & 15.24 \\
\hline High cost of inputs & 84 & 40 \\
\hline Scarcity of inputs & 78 & 37.14 \\
\hline Difficulty in accessing farmland & 09 & 4.28 \\
\hline Poor capital base & 58 & 27.62 \\
\hline Difficulty to access credit & 67 & 31.90 \\
\hline Malicious damage of crops by pastoralists & 51 & 24.28 \\
\hline In-security & 11 & 5.24 \\
\hline Poor storage facilities & 47 & 22.38 \\
\hline Low market value & 41 & 19.52 \\
\hline Problem of mobility & 11 & 5.24 \\
\hline Problem of parasitic weeds & 11 & 5.24 \\
\hline Farm traction and human drudgery & 07 & 3.33 \\
\hline Abnormal seasonal changes & 05 & 2.38 \\
\hline High weeds density & 02 & 0.95 \\
\hline Inadequate labour & 05 & 2.38 \\
\hline Marketing & 03 & 1.43 \\
\hline
\end{tabular}

Source: Field survey, 2015. *multiple responses exist

\section{Summary, Conclusion and Recommendations}

\subsection{Summary}

The study analyzed the role of socio-economic factors influencing the use of insecticides by Cowpea farmers in Fufore Local Government Area of Adamawa State. The broad objective of the study is to analyze the socio-economic factors influencing the use of insecticides for control of cowpea pests by cowpea farmers of Fufore Local Government Area, Adamawa State, Nigeria. The specific objective were to describe the socio-economic characteristics of the respondents, identify the common insecticides used by the respondents, determine the costs of insecticides incurred per unit area to control cowpea pests by the respondents, determine the socio-economic factors influencing the use of insecticides for control of cowpea pests by the respondents and identify the measure constraints encountered by respondents in cowpea production in the study area. Primary data was collected using structured questionnaires which was administered to 210 respondents selected using Multi-stage, Stratified Random and Purposive sampling techniques from 6 out of 11 wards in the Local Government Area. The data obtained were analyzed by the use of descriptive statistics and inferential statistics.

The result revealed that $29.05 \%$ of the respondents were within the age of 40-49 years with the mean age is $43,84.76 \%$ were male, $90.48 \%$ were married, $32.86 \%$ have family size of $6-10$ persons which is moderate and mean of 11 . Furthermore, $16.67 \%$ of the respondents had primary education, $27.62 \%$ had secondary education, $3.33 \%$ had certificate and $9.05 \%$ had tertiary 
education, while $43.33 \%$ had no formal education. Also, $73.81 \%$ were engaged in one form of farming or another as major occupation, 36.19\% had 6-10 years farming experience, 56.19\% cultivate farm size of 1-2.5 ha, and only $10 \%$ of the respondents had extension contacts.

The entire respondents used modern insecticides whereby Cypermethrin 10EC or 10\% EC was mostly used followed by Lambda-Cyhalothrin. The research further revealed that the insecticides were mostly applied without following approved recommendations of which $45.24 \%$ apply $4-6$ times at an interval of 7 days among the respondents. All the respondents used hydraulic knapsack sprayers. An average of N3,737.17 was incurred in procuring insecticides to control Cowpea Pests per hectare. $69.52 \%$ of the respondents were influenced by age, desire for higher yield and good quality grains. The use of insecticides by the respondents is influenced directly by their educational level (0.014115), household size (0.004386), farming experience (0.008612) and farm size (0.036816). Similarly, age of the respondents inversely affects their decision to use insecticides ($0.003066)$.

The respondents encountered various constraints in the study area which include; insect pests, weak extension services, high cost and scarcity of inputs, poor capital base and difficulty to access credit, poor storage facilities etc.

\subsection{Conclusion}

Based on the findings of the research, it is concluded that majority of the respondents (29.05\%) were at their active age of $40-49$ years, with mean age of 43 , most of them $(84.76 \%)$ were male, $90.48 \%$ were married, majority $(32.86 \%$ ) had family size $6-10$, and $56.67 \%$ had one form of formal education or another, $73.81 \%$ were engaged in farming. Majority of the respondents used Cypermethrin 10EC or 10\% EC and Lambda-cyhalothrin insecticides to control cowpea pests. And average cost of N3,737.17 was incurred in procuring insecticides per hectare. The multiple regression (linear function) used to identify the factors that influence the application of insecticides in the study area shows that, age of the farmer (X2), household size (X3), educational attainment of the farmer (X4), farming experience of the respondent (X5) and farm size of the respondent (X6) were all significant at 1\%,5\% and 10\% respectively. The major constraints encountered by the respondents in the study area were insect pests, high cost and scarcity of inputs. The respondents found it imperative in using modern insecticides for control of cowpea pests in the study area.

It could be concluded that the use of insecticides for control of pests in Cowpea production will not only lead to food security among farmers in the production area, but will help in general food security all over the country since Cowpea is an important protein food consumed far beyond the immediate production area.

\subsection{Recommendations}

Based on the conclusions of the study, the following recommendations are hereby made:

1) Effective insecticides that are pests targeted should be made available for farmers to access as at and when due (Gumel, 2008), at subsidise rate

2) Youths should be encouraged to engage on cowpea production in the study area 
3) Government should have a political will towards agriculture so as to improve extension services, for guide to farmers on activities associated with pest control in Cowpea production

4) Cowpea farmers should be promptly enlightened on dangers of parasitic weeds, high weeds density, abnormal seasonal changes and effective ways of managing cowpea pests

5) Cowpea farmers should adopt integrated pest management (IPM) as a remedy to pests problems in cowpea production

\section{References}

[1] Acquaah, G. (2005). Principles of production: Theory, Techniques and Technology, prentice-Hall, inc., New Delhi, India.

[2] Adebayo, A.A. and Tukur, A.L. (1999). Adamawa State in Maps, First edition, Paraclete publishers, Yola. Nigeria.

[3] Ahmed, I.A., Kutama, A.S., Maryam, T.A., Aminu, Y. and Naziru, A.B. (2014). The preponderance of pod sucking Bugs of Cowpea and their control using synthetic insecticides in Samaru, Nigeria. Journal of Scientific Research, Vol.2(2), February, 2014. http://www.researchwebpub. org/wjsr Accessed on 15/9/2014.

[4] Ani, A.O. (2007). Agricultural Extension: A Pathway for sustainable Agricultural Development, Apani Publications, Kaduna, Nigeria.

[5] Ba, A.M., Galtima M. and Tukur, A.L. (2014). Assessment of Environmental Changes in the Fufore Area of Adamawa State, Nigeria. Journal of Environmental Science, Toxicology and food Technology, Volume 8, issue 5 ver. IV, May, 2014 Accessed on 11/02/2015.

[6] Booker, R.H. (1965). Pests of Cowpea and their control in Northern Nigeria. Bulletin of Entomological Research 55:663-672.

[7] Baur, F.J. (1984) "Chemical Methods to Control insect Pests of Processed Foods" In Insect Management for Food Storage and Processing, Baur, F.J. (ed), American Association of cereal Chemists, St. Paul MN, U.S.A.

[8] Consultative Group for International Agricultural Research (2014). http://www.cigar.org/ourresearch/Crop-factsheets/cowpea/ Accessed on 10/10/2014.

[9] Davis, D.W., Oelke, E.A., Oplinger, E.S., Doll, J.D., Hanson, C.V. and Putnam, D.H. (1991). Cowpea Research, Production and utilization, Wiley and Sons U.S.A.

[10] Daxl, R., Kayser, L.N.V., Klein-Koch, C., Link, R. and Waibel, H. (1994). Integrated Pest Management; Guidelines, Deutshe GTZ, Germany.

[11] De Fliert, E.V. and Winarto, Y.T. (2006). "From Technological Packages to ecological principles", LEISA Magazine, Special Issue, 2006.

[12] Dent, D. (1993). Insect Pest Management, CAB International, Wallingfood, UK.

[13] Dugje, I.Y., Omoigui, L.O., Ekeleme, F., Kamara, A. Y. and Ajeigbe, H. (2009). Farmers' Guide to Cowpea Production in West Africa, International Institute for Tropical Agriculture, Ibadan, Nigeria.

[14] Egho, E.O. (2011). Management of Major Field Insect Pests and yield of Cowpea (Vigna unguiculata $\{\mathrm{L}\}$ Walp) under Calendar and Monitored Application of Synthetic Chemicals in Asaba, Southern - Nigeria. American Journal of Scientific and Industrial Research. http://www.scihub.org/AJSIR. Accessed on 15/9/2014.

[15] Elizabeth, S., Bashir, R.M., Gidado, A.S., Sani, R.M. and Adeniji, O.T. (2014). Investigation on Production Constraints and adoption of Inorganic Insecticised and Spraying Regime in Management of Cowpea (Vigna Unguiculata L.Walp) Insects in Mubi Zone, Nigeria. Journal of Agricultural Extension and Rural Development, Vol. 6(1)

http://www.academicjournal.org/JAERD Accessed on 05/08/2015. 
[16] van Emden, H.F. (1989). Pest Control, Second edition, Cambridge University press, United Kingdom.

[17] Fleischer, G. (2006). "Agricultural Chemicals - How much input is required, how much is too much?” Agriculture and Rural Development Magazine, Vol.13, No.1, 512006.

[18] Fufore Local Government Area at a Glance (2013).

[19] Futuless, K.N., Bake, I.D. and Tizhe, W. (2010). Effect of Sowing Date on Yield Components of Cowpea (Vigna Unguiculata L.Walp) in Mubi-North Local Government Area, Adamawa State, Nigeria. New York Science Journal, 3(11) 17-19. http://www.sciencepub.net Accessed on 05/08/2015.

[20] Futuless, K.N. and Bake I.D. (2010). Evaluation of Yield and Yield Attributes of some Cowpea (Vigna Unguiculata L.Walp) Varieties in Northern Guinea Savanna. Journal of American Science Vol. 6(8) 21-23. http://www.americanscience.org Accessed on 05/08/2015.

[21] Gumel, M.A.A. (2008). Cowpea Production Technology, A one day workshop paper on capacity Building of Facilitators, organized by Adamawa State Farming Skills Acquisition Programme, held on 6th November, 2008.

[22] Haddabi, A.S. (2009). Promotion of Integrated Pest Management (IPM) in Cowpea Production in Fufore Local Government Area, Adamawa State, Nigeria. Unpublished Article.

[23] Isah, H., Adebayo, E.F., Bala, M. and Gwandi, O. (2013). Profitability of Sole Cowpea Production in Gombi Zone of Adamwa State Agricultural Development Programme, Nigeria. American Journal of Advanced Agricultural Research (AJAAR), Vol.1, Issue 1. Accessed on 05/08/2015.

[24] International Institute for Tropical Agriculture (2014). Cowpea www.iita.org/copwea. Accessed on $10 / 10 / 2014$.

[25] Jackai, L.E.N. and Adalla, C.B. (1997). "Pest Management Practices in cowpea: a review" In Advances in Cowpea Research, Singh, B.B., mohan, R.D.R., Dashiell, K.E. and Jackai., L.E.N. (eds), IITA Ibadan and Japan International Research Center, Tsukuba, Ibaraki, Japan.

[26] Kedebe, Y., Kunjal, K. and Goffal, G. (1990). Adoption of New Technologies in Ethiopian Agriculture: The Case Tegulet-Bulga District Shoa Province. Agricultural Economics 4, 27-43.

[27] Kennedy, D. (1975). Contemporary Pest Control Practices and Prospects, Vol.1 National Academy of Sciences, Washington, D.C.

[28] Kochhar, S.L. (1986). Tropical Crops: a Textbook of economic Botany, Macmillan publishers, Delhi., India.

[29] Kolke, G.V. and Kern, M. (2006). "Chemicals for the poorest: Hazard or Chance?” Agriculture and Rural Development Magazine, Vol. 13, No. 1 48-50 2006.

[30] Matthews, G., wiles, T. and Baleguel, P. (2003). "A survey of pesticide Application in Cameroon", Crop Protection Journal, Vol. 22, No.5, 22, June, 2003.

[31] Musa, Y.H., Vosanka, I.P., Inuwa, A. and Mohammed, S. (2010). Economic Analysis of Cowpea Production in Donga Local Government Area of Taraba State, Nigeria, Journal of Sciences and Multidisciplinary Research: www/cenresin.org Vol.16, NO.11, 19. Accessed on 15th /9/2014.

[32] Ogunbameru, B.O. (2001). Practical Agricultural Communication, Daily Graphics Nig. Itd., Ibadan Nigeria.

[33] Omolehin, R.A., Ogunfiditimi, T.O. and Adeniji, O.B. (2007). "Factors Influencing Adoption of Chemical Pest Control in Cowpea Production among Rural Farmers in Makarfi Local Government Area of Kaduna State, Nigeria.” Journal of Agricultural Extension, Vol.10, 52007.

[34] Opeke, L.K. (2006). Essentials of Crop Farming, First Edition, Spectrum Books Limited, Ibadan, Nigeria.

[35] Oyewale, R.O., Bello L.Y., Idowu, G.A., Ibrahim H.M. and Isah, A.S. (2014). Rate of Insecticide Formulations on the Damage Assessment, Yield and Yield Components of Cowpea, International Journal of Current Microbiology and Applied Sciences, Volume 3, Number 2, 2014 http:www.ijcmas.com Accessed on 15/9/2014. 
[36] Palm, C.E., Dykstra,w.w., Ferguson, G.R., Hansberry, R., Hayes Jr., W.J., Hazleton, L.W., Horsfall, J.G., Knipling, E.F., Leach, L.D., Lovvorn, R.L. and Swanson, G.A. (1971). Insect Pest Management and Control, Vol.3, National Academic of Sciences, Washington D.C.

[37] Rothschild, G.H.L. (1992). Integrated Pest Management in Developing Countries; Experience and Prospects, Natural Resources Institute, Chatham Maritime, United Kingdom.

[38] Sasakawa Global 2000 Nigeria Project (2010). A Simplified Guide for Crop Production Practices in Nigeria.

[39] Schuler, B. (2006). "Chemicals Management: What dialogue and Training can Achieve", Agriculture and Rural Development Magazine, Vol.13, No. 1, 2006.

[40] Sherwood, S., Cole. D. and Murray, D. (2007). "It's time to Ban Highly Hazardous Pesticides", LEISA Magazine, Vol. 23, No.3, September, 2007.

[41] Shinggu, D.Y. and Daniel, J.D. (2010). Effect of Karate 25EC, Neem Seed Aqueous Extract and Cigarette Filter Extract on the Yield of Ife-Brown in Mubi, Adamawa State, Nigeria. Scholars Research Library, Vol. 2(6) 27. (http://scholarresearchlibrary.com/archieve.html) Accessed on 05/08/2015.

[42] Singh, S.R. and Rachie, K.O. (1985). Cowpea: Research, Production and utilization, IITA, John Wiley and Sons, Great Britain.

[43] Tijjani, O. R. (2003). Socio-Economic Assessment of Pesticide-Use Among Cowpea Farmers in Ibarapa Local Government Area of Oyo State, Nigeria. An Undergraduate Project Submitted to the Department of Agricultural Economics and Farm Management, Federal University of Agriculture, Abeokuta. Retrieved 18th August, 2016 from: www.journal.unaab.edu.ng/index.php/theses.

[44] Tijani, A.A., Oshotimehin, K.O. (2007). Economics of pesticides use among Maize farmers in Edo state, Nigeria. Research Journal of Agricultural Biological Sciences, 3(3), 129-132.

[45] Williamson, S., Ball, A. and Pretty, J. (2008). Trends in pesticide use and drivers for safer pest management in four African countries. Crop Protection 27, 1327- 1334. Retrieved 18th August, 2016 from: www.elsevier.com/locate/cropro

[46] Zalkuwi, J., Maurice, D.C. and Yusuf, C. (2014). Determinant of Cost Efficiency in Cowpea Production: A case Study of Adamawa State, Nigeria. International Journal of Science and Research (IJSR), Volume 3, Issue 9, 2-10 September,

*Corresponding author.

E-mail address: abdualiyu14@ymail.com 